\title{
Hubungan Pengeluaran Rumah Tangga, Asupan Protein, Dan Asupan Zat Besi Dengan Kadar Hemoglobin Pada Pekerja Tambang Pasir Tradisional
}

\section{Correlation between Household Expenditure, Protein Intake, Iron Intake and Haemoglobin Level among the Traditional Sand Miner}

\author{
Syahid Kinayung Widyaji* ${ }^{1}$, Trias Mahmudiono ${ }^{1}$
}

\begin{abstract}
ABSTRAK
Latar Belakang: Anemia merupakan salah satu masalah gizi pada masyarakat dengan status sosial ekonomi yang rendah. Pada sosial ekonomi yang rendah cenderung asupan zat gizinya rendah karena terbatasnya akses ke pangan yang beragam.

Tujuan: Untuk menganalisis hubungan antara pengeluaran rumah tangga, asupan protein, dan asupan zat besi dengan kadar hemoglobin pada pekerja tambang pasir tradisional.

Metode: Penelitian ini menggunakan desain cross sectional dengan besar sampel 58 pekerja tambang pasir tradisional yang dipilih menggunakan simple random sampling. Pengumpulan data dilakukan dengan wawancara menggunakan kuesioner, $2 \times 24$ hours food recall, dan kadar hemoglobin diukur dengan alat Easy Touch GCHb. Uji statistik yang digunakan adalah korelasi pearson.

Hasil: Hasil penelitian menunjukkan terdapat hubungan pengeluaran rumah tangga $(p=0,016)$ dan asupan protein $(p=0,037)$ dengan kadar hemoglobin. Sebaliknya tidak terdapat hubungan asupan zat besi $(p=0,258)$ dengan kadar hemoglobin.

Kesimpulan: Pengeluaran rumah tangga dan asupan protein berhubungan dengan kadar hemoglobin pada pekerja tambang pasir tradisional.
\end{abstract}

Kata Kunci: kadar hemoglobin, pekerja tambang pasir tradisional, asupan zat gizi

\section{ABSTRACT}

Background: Anemia is one of the nutritional problem in society with low socioeconomic status. Low socioeconomic associated with lower nutritional intake do to limited access to a variety of foods. Objective: the aim of this study was to analyze the relationship netween household expenditure and intake protein with hemoglobin level among sand miner.

Method: this was a cross sectional study with 51 sample sand miner was selected by simple random sampling. The data were collected through interview using questionnaire, $2 \times 24$ hours food recall, and hemoglobin level measured by Easy Touch GCHb. Data were analyzed using Pearson correlation.

Result: The result showed that there were associations between household expenditure $(p=0.016)$ and intake protein $(p=0.037)$ to hemoglobin level. Conversely, there was no association between intakes of iron to hemoglobin level.

Conclusion: Household expenditure and intake protein related to the hemoglobin level among sand miner.

Conclusion : Patient satisfaction of food by outsourcing system was no difference from the patient satisfaction of food by self operated system.

Keywords: hemoglobin level, sand miner, nutrient intake 
*Koresponden:
syahidkinayung@gmail.com
${ }^{1}$ Departemen Gizi Kesehatan, Fakultas
Kesehatan Masyarakat-Universitas Airlangga

\section{PENDAHULUAN}

Berkurangnya kesempatan dan ketersediaan lapangan pekerjaan menyebabkan sebagian masyarakat berupaya untuk membuka lapangan pekerjaan dengan memanfaatkan sumber daya alam yang tersedia. Keberadaan masyarakat pada aliran sungai yang terdapat pasir akan dimanfaatkan untuk menjadi pekerja tambang pasir tradisional. Pekerjaan sebagai pekerja tambang pasir tradisional dapat mengurangi pengangguran dan mencukupi kebutuhan ekonom ${ }^{1}$.

Pekerja tambang pasir tradisional termasuk pekerjaan yang pendapatannya rendah $^{1}$. Pendapatan akan mempengaruhi tingkat konsumsi dan pengeluaran, dimana pada masyarakat yang pendapatannya rendah menyebabkan rendahnya daya beli sehingga kualitas konsumsi makanan akan rendah ${ }^{2}$. Penurunan kualitas konsumsi ditandai dengan konsumsi makanan hewani yang cenderung rendah dan pemenuhannya tidak menjadi prioritas $^{3}$. Makanan hewani merupakan sumber zat besi ${ }^{4}$. Salah satu dampak dari rendahnya asupan zat besi dapat menyebabkan terjadinya anemia defisiensi besi ${ }^{5}$. Anemia defisiensi besi dapat menyebabkan penurunan produktifitas kerja ${ }^{4}$.

Anemia merupakan suatu keadaan dimana kadar hemoglobin $(\mathrm{Hb})$ dalam darah dibawah normal yang diakibatkan oleh defisiensi salah satu atau beberapa zat gizi yang dibutuhkan dalam pembentukan sel darah merah ${ }^{6}$. Penyebab utama dari anemia adalah defisiensi zat besi ${ }^{7}$. Faktor yang dapat menyebabkan terjadinya anemia defisiensi besi adalah asupan zat besi yang rendah, terhambatnya penyerapan zat besi, kebutuhan yang meningkat pada pendarahan akibat parasit, dan kehilangan zat besi disebabkan infeksi cacing dalam usus ${ }^{7}$. Faktor lain yang dapat menyebabkan terjadinya anemia defisiensi besi adalah asupan protein yang rendah $^{8}$. Salah satu penyebab dari rendahnya asupan protein terutama dari hewani adalah pendapatan yang rendah ${ }^{9}$. Pendapatan yang rendah akan mempengaruhi akses rumah tangga pada pangan ${ }^{10}$.

Kabupaten Lumajang menjadi tempat keberadaan aliran sungai dari Gunung Semeru yang membawa berkah bagi masyarakat dengan melimpahnya bahan galian golongan $\mathrm{C}$ khususnya pasir ${ }^{11}$. Desa Pronojiwo merupakan salah satu desa yang menjadi tempat tinggal pekerja tambang pasir tradisional ${ }^{12}$. Berdasarkan studi pendahuluan didapatkan bahwa pendapatan dari pekerja tambang pasir tradisional di Desa Pronojiwo tidak menentu karena tergantung dari ketersediaan pasir dan jumlah pembeli pasir. Pada lokasi lain yaitu di aliran Sungai Tajum Kabupaten Banyumas, hasil penelitian Sudjarwanto \& Sugito (2007) menyatakan bahwa penambang pasir pendapatannya rendah $^{1}$.

Berdasarkan uraian diatas, perlu dilakukan penelitian mengenai kadar hemoglobin pada pekerja tambang pasir tradisional. Penelitian ini bertujuan untuk hubungan pengeluaran rumah tangga, asupan protein, dan asupan zat besi dengan kadar hemoglobin pada pekerja tambang pasir tradisional di Desa Pronojiwo, Kecamatan Pronojiwo, Kabupaten Lumajang.

\section{METODE}

Penelitian ini merupakan penelitian observasional analitik dengan desain cross sectional. Populasi dalam penelitian ini adalah seluruh kepala rumah tangga bermata pencaharian sebagai pekerja tambang pasir tradisional di Desa Pronojiwo, Kecamatan Pronojiwo, Kabupaten Lumajang. Besar sampel sebanyak 58 responden dan terpilih 
secara acak dengan menggunakan simple random sampling.

Pengumpulan data pada penelitian ini dilakukan dengan wawancara menggunakan kuesioner yang meliputi karakteristik responden (pendidikan, usia, jumlah anggota keluarga, pendapatan rumah tangga, dan pengeluaran rumah tangga). Data asupan protein dan zat besi diperoleh dengan metode $2 \times 24$ hours food recall dan diolah dengan software Nutrisurvey 2007. Kadar Hemoglobin $\mathrm{Hb}$ ) diukur di lapangan dengan menggunakan alat Easy Touch $\mathrm{GCHb}$. Untuk menganalisis hubungan pengeluaran rumah tangga, asupan protein, dan asupan zat besi dengan kadar hemoglobin pada pekerja tambang pasir tradisional dilakukan uji statistika korelasi pearson.

\section{HASIL DAN PEMBAHASAN}

Rata-rata kadar hemoglobin responden adalah 13,5 $\pm 1,8 \mathrm{~g} / \mathrm{dl}$. Mayoritas tingkat pendidikan terakhir pada pekerja tambang pasir adalah tamat SMP/sederajat $(43,1 \%)$. Sebanyak 19 (32.8\%) berusia 31-40 tahun. Jumlah anggota keluarga responden berkisar 2-6 orang, sebagian besar $49(84,5 \%)$ dalam kategori keluarga kecil dan $9(15,5 \%)$ adalah keluarga besar. Rata-rata pendapatan rumag tangga adalah Rp. 2.086.724,14.

Pengeluaran rumah tangga menjadi indikator daya beli terhadap pangan sehingga akan mempengaruhi konsumsi pangan dalam rumah tangga ${ }^{13}$. Pengeluaran rumah tangga yang diutamakan untuk pemenuhan pangan memungkinkan terpenuhinya konsumsi pangan dengan kualitas gizi yang baik sehingga dapat memenuhi kebutuhan tubuh ${ }^{14}$.

Tabel 1. Distribusi Frekuensi Karakteristik Responden

\begin{tabular}{|c|c|}
\hline \multirow{2}{*}{ Karakteristik } & Total $(n=51)$ \\
\hline & $\mathrm{n}(\%)$ \\
\hline \multicolumn{2}{|l|}{ Pendidikan } \\
\hline Tidak sekolah & $6(10,3)$ \\
\hline Tamat SD/sederajat & $19(32,8)$ \\
\hline Tamat SMP/sederajat & $25(43,1)$ \\
\hline Tamat SMA/sederajat & $8(13,8)$ \\
\hline \multicolumn{2}{|l|}{ Usia } \\
\hline 20-30 tahun & $7(12,1)$ \\
\hline 31-40 tahun & $19(32,8)$ \\
\hline 41-50 tahun & $17(29,3)$ \\
\hline$>50$ tahun & $15(25.9)$ \\
\hline $\begin{array}{l}\text { Jumlah } \quad \text { Anggota } \\
\text { Keluarga }\end{array}$ & \\
\hline Kecil ( $\leq 4$ orang) & $49(84,5)$ \\
\hline Besar (> 4 orang) & $9(15,5)$ \\
\hline
\end{tabular}

Tabel 2. Rata-rata dan hasil uji korelasi dengan kadar $\mathrm{Hb}$

\begin{tabular}{|c|c|c|c|c|c|c|}
\hline Variabel & $\mathbf{N}$ & Mean & SD & Min & Max & p-value \\
\hline $\begin{array}{l}\text { Pendapatan } \\
\text { rumah tangga }\end{array}$ & 58 & $2.086 .724,14$ & $499.191,06$ & 1.450 .000 & 4.050 .000 & \\
\hline $\begin{array}{l}\text { Pengeluaran } \\
\text { Rumah Tangga }\end{array}$ & 58 & $1.822 .827,59$ & $436.296,74$ & 1.240 .000 & 3.996 .000 & 0,016 \\
\hline Asupan Protein & 58 & 38,35 & 11,32 & 15 & 61 & 0,037 \\
\hline Asupan Zat Besi & 58 & 7,64 & 2,42 & 3 & 16.4 & 0,258 \\
\hline Kadar Hb & 58 & 13,5 & 1,8 & 7.5 & 18.3 & \\
\hline
\end{tabular}




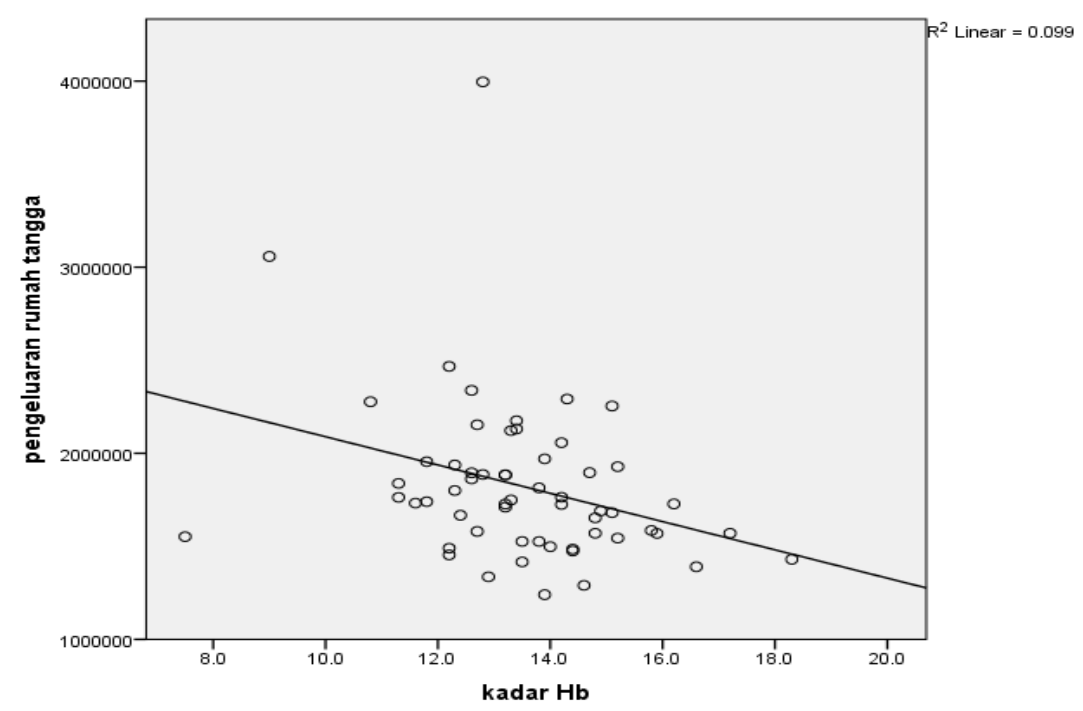

Gambar 1. Kadar Hemoglobin menurut Pengeluaran Rumah Tangga

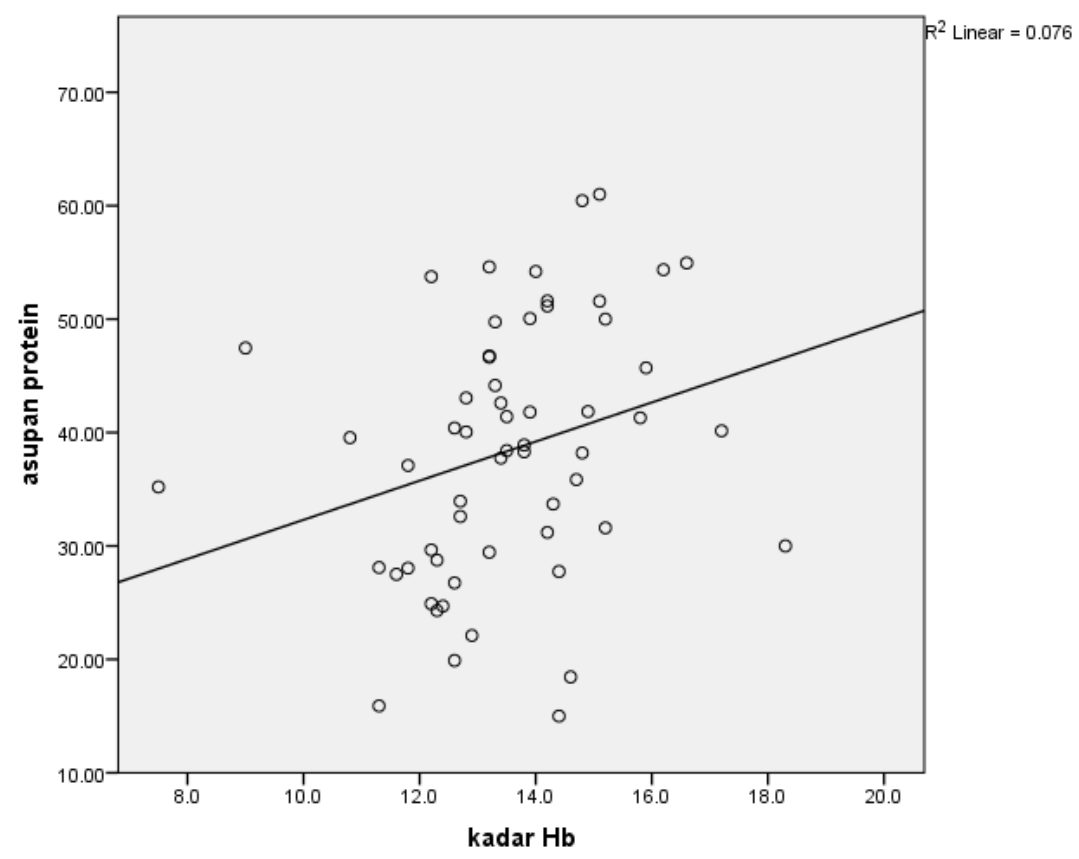

Gambar 2. Kadar Hemoglobin menurut Asupan Protein

Rata-rata pengeluaran rumah tangga dalam sebulan adalah Rp. 1.822.827,59. Hasil uji statistika menunjukkan bahwa terdapat hubungan antara pengeluaran rumah tangga dengan kadar hemoglobin $(p=0,016)$. Hal ini sejalan dengan penelitian Argana, et al. (2004) yang menyatakan bahwa pengeluaran rumah tangga berhubungan dengan kadar hemoglobin $^{15}$. Pengeluaran rumah tangga akan meningkat disaat terjadi peningkatan pendapatan sehingga konsumsi pangan yang memperhatikan kualitasnya akan terpenuhi ${ }^{3}$. Pengeluaran rumah tangga juga dijadikan sebagai indikator kesejahteraan masyarakat, dimana semakin rendah alokasi pengeluaran rumah tangga untuk pangan maka tingkat ekonominya akan semakin baik $^{16}$. 


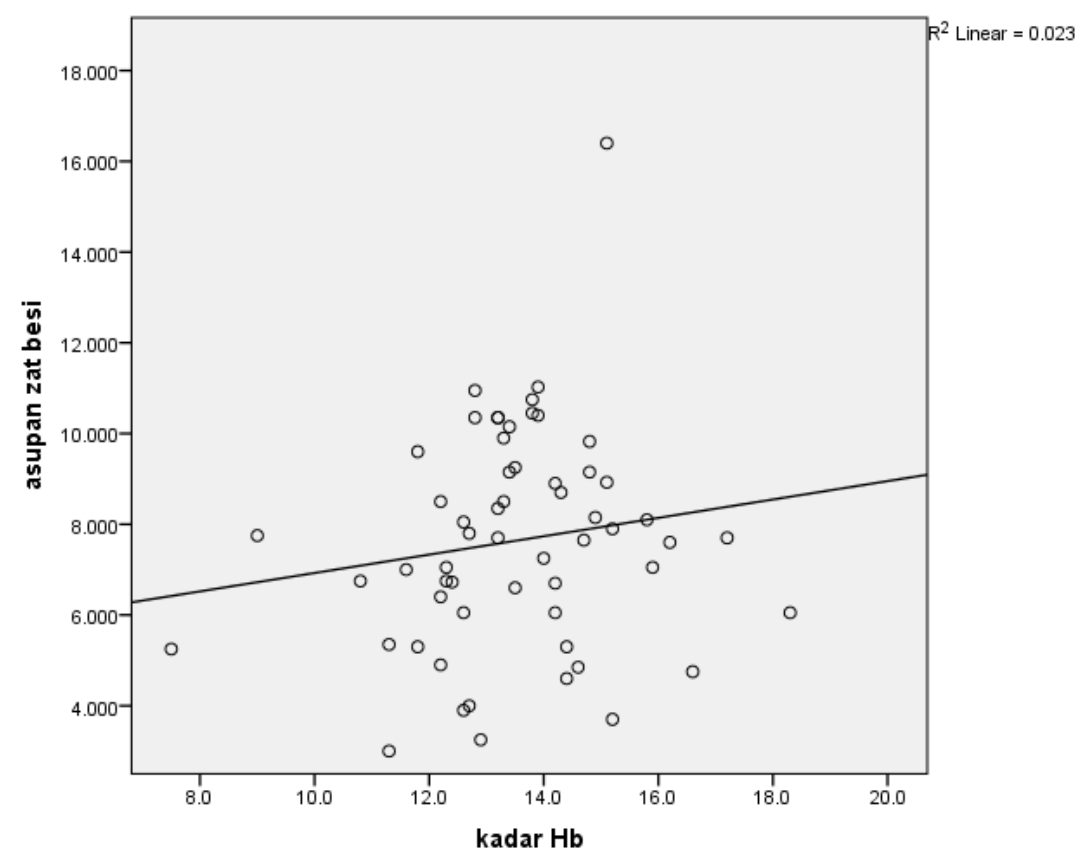

Gambar 3. Kadar Hemoglobin menurut Asupan Zat Besi

Protein mempunyai fungsi khusus yang tidak dapat digantikan oleh zat gizi lainnya yaitu membangun serta memelihara sel dan jaringan tubuh ${ }^{17}$. Rata-rata asupan protein responden dibawah dari angka kecukupannya yaitu sebesar $38,35 \mathrm{~g}$ (<77\% AKG). Hasil uji statistika menunjukkan bahwa terdapat hubungan antara asupan protein dengan kadar hemoglobin $(p=0,037)$. Hasil penelitian ini selaras dengan penelitian yang dilakukan Yani, et al. (2015) bahwa terdapat hubungan antara tingkat konsumsi protein dengan kadar hemoglobin ${ }^{18}$.

Dilihat dari hasil $2 \times 24$ hours food recall sebagian besar asupan protein didapatkan dari protein nabati. Responden kurang mengonsumsi bahan makanan sumber protein hewani dimana mutu proteinnya lebih baik dibandingkan dengan protein nabati ${ }^{19}$. Selain mutu proteinnya lebih baik, konsumsi makanan hewani seperti daging sapi, daging ayam, dan ikan dapat meningkatnya penyerapan zat besi dari makanan nabati sampai 2-3 $\mathrm{kali}^{20}$. Jumlah protein yang rendah dalam tubuh menyebabkan proses pengangkutan zat besi ke sel darah merah berkurang sehingga akan terjadi gangguan pengangkutan dan penyerapan zat besi ${ }^{21}$.

Zat besi merupakan bahan utama dalam pembentukan hemoglobin sehingga zat besi didalam tubuh yang kurang akan berdampak pada terganggunya pembentukan hemoglobin ${ }^{22}$. Rata-rata asupan zat besi responden dibawah dari angka kecukupannya yaitu sebesar 7,64 mg (< EAR). Hasil uji statistika menunjukkan bahwa tidak terdapat hubungan antara asupan zat besi dengan kadar hemoglobin $(p=0,258)$. Hasil penelitian ini sejalan dengan Matayane, et al. (2013), tidak terdapat hubungan antara asupan zat besi dengan kadar hemoglobin ${ }^{23}$.

Dilihat dari hasil $2 \times 24$ hours food recall didapatkan bahwa kurangnya konsumsi makanan sumber zat besi yang terdapat pada makanan hewani dalam bentuk heme. Responden lebih sering mengonsumsi sumber zat besi yang terdapat makanan nabati dalam bentuk non-heme. Rendahnya asupan zat besi tidak selalu menyebabkan kadar hemoglobin rendah karena cadangan besi dalam tubuh masih mencukupi sehingga kebutuhannya terpenuhi ${ }^{22}$.

Tidak terdapatnya hubungan asupan zat besi dan kadar hemoglobin pada penelitian ini kemungkinan karena pada saat dilakukan $2 \times 24$ hours food recall, makanan yang dikonsumsi dalam sehari sama dan melaporkan porsi atau jumlah yang sama pada tiap kali makan sehingga tidak menggambarkan asupan yang sebenarnya. Selain itu, faktor daya ingat dan 
kejujuran juga berpengaruh pada keberhasilan dalam melakukan food recall ${ }^{20}$.

Kelebihan dari penelitian ini adalah belum adanya publikasi lain yang sejenis, sedangkan kekurangan pada penelitian ini adalah tidak ditelitinya pengetahuan gizi sehingga tidak dapat diketahui seberapa jauh pengetahuan responden tentang makanan yang berpengaruh pada kadar hemoglobin dan akurasi dari alat pemeriksaan kadar hemoglobin lebih rendah apabila dibandingkan dengan metode Cyanmethemoglobin.

\section{KESIMPULAN}

Rata-rata kadar hemoglobin pada penelitian ini adalah $13.5 \mathrm{~g} / \mathrm{gl}$. Terdapat hubungan antara pengeluaran rumah tangga dan asupan protein dengan kadar hemoglobin pada pekerja tambang pasir tradisional, sebaliknya tidak ada hubungan asupan zat besi dengan kadar hemoglobin pada pekerja tambang pasir tradisional.

Diharapkan untuk penelitian selanjutnya menambahkan pengetahuan gizi serta pemeriksaan kadar hemoglobin menggunakan metode Cyanmethemoglobin.

\section{ACKNOWLEDGEMENT}

Peneliti mengucapkan terima kasih kepada petugas Puskesmas Pronojiwo dan perangkat Desa Pronojiwo yang telah membantu kelancaran penelitian ini baik secara tenaga maupun masukan-masukan.

\section{REFERENSI}

1. Sudjarwanto, Sugito. 2007. Kemiskinan pada keluarga penambang pasir di tiga desa daerah aliran Sungai Tajum Kabupaten Banyumas. Jurnal Pembangunan Pedesaan ;7(1):26-31.

2. Kementerian Perdagangan. 2015. Laporan akhir analisi dinamika konsumsi pangan masyarakat di Indonesia. Available at http://www.kemendag.go.id/files/pdf/20 15/02/27/laporan-dinamika-pola- 1425036045.pdf. Diakses pada 15 Juli 2017.

3. Ermawati, Reny O. 2011. Analisis ketahanan pangan rumah tangga miskin pada daerah rawan banjir di Kecamatan Jebres Kota Surakarta. Skripsi. Surakarta: Fakultas Pertanian Universitas Sebelas Maret.

4. Almatsier, S. 2009. Prindip dasar Ilmu gizi. Jakarta: PT Gramedia Pustaka Utama.

5. Arisman. 2010. Gizi dalam daur kehidupan. Jakarta: Penerbit Buku Kedokteran.

6. Kementerian Kesehatan. 2013. Buku saku asuhan gizi di Puskesmas. Jakarta: Kementerian Kesehatan dan WHO Indonesia.

7. Masrizal. 2007. Anemia defisiensi besi. Jurnal Kesehatan Masyarakat ;II(1). p. 140-145.

8. Andarina D, Sumarmi S. 2006. Hubungan konsumsi protein hewani dan zat besi dengan kadar hemoglobin pada balita usia 13-36 bulan. The Indonesia Journal of Public Health ;3(1):19-23.

9. Sinaga RJR, Lubis SN, Darus MB. 2015. Kajian faktor-faktor sosial ekonomi masyarakat terhadap ketahanan pangan rumah tangga di Medan. Available at https://jurnal.usu.ac.id/index.php/ceress /article/viewFile/7876/3339. Diakses pada 15 Juli 2017.

10. Hanani N. 2009. Pengertian ketahanan pangan. Available at http://nuhfil.lecture.ub.ac.id/files/2009/0 3/2-pengertian-ketahanan-pangan-2.pdf. Diakses pada 15 Juli 2017.

11. Peraturan Daerah Kabupaten Lumajang Nomor 18 Tahun 2006 Tentang Surat Ijin Penambangan Daerah.

12. Badan Pusat Statistika. 2016. Kecamatan Pronojiwo dalam angka. Lumajang: BPS.

13. Mulyo JH, Sugiyarto, Widada AW. 2015. Ketahanan dan kemandirian pangan rumah tangga tani daerah marjinal di Kabupaten Bojonegoro. Jurnal Agro Ekonomi; 26(2): 121-128.

14. Purwaningsih $Y$, Hartono $S$, Masyuri, Mulyo JH. 2010. Pola pengeluaran pangan rumah tangga menurut ketahanan pangan di Provinsi Jawa 
Tengah. JurnalEkonomi Pembangunan; 11(2): 236-253.

15. Argana G, Kusharisupeni, Utari DM. 2004. Vitamin $C$ sebagai faktor dominan untuk kadar hemoglobin pada wanita usia 20-35 tahun. Jurnal Kedokteran Trisakti; 23(1): 6-14.

16. Arida A, Sofyan, Fadhiela K. 2015. Analisis ketahanan pangan rumah tangga berdasarkan proporsi pengeluaran pangan dan konsumsi energi. Agrisep; 16(1): 20-34.

17. Diana, FM. 2009. Fungsi dan metabolisme protein dalam tubuh manusia. Jurnal Kesehatan Masyarakat; 4(1): 47-52.

18. Yani IE, Dwiyanti D, Hamid S. 2015. Asupan zat gizi dan kadar hemoglobin pada anggota Indonesia Vegetarian Society (IVS) Cabang Padang. Jurnal Sehat Mandiri; 10(1): 103-110.

19. Hardinsyah, Riyadi H, Napitupulu V. 2012. Kecukupan energi, protein, lemak, dan karbohidrat. Available at https://www.researchgate.net/profile/Ha di_Riyadi/publication/301749209_KECUK
UPAN_ENERGI_PROTEIN_LEMAK_DAN_K ARBOHIDRAT/links/57254d4b08aef9c00b $846 \mathrm{bOa} /$ KECUKUPAN-ENERGI-PROTEINLEMAK-DAN-KARBOHIDRAT.pdf. Diakses pada 2 Agustus 2017.

20. Pakar Gizi Indonesia. IImu gizi teori dan aplikasi. Jakarta: Penerbit Buku Kedokteran EGC. p. 43-46, 87.

21. Anggraini L, Lestariana $W$, Susetyowati. 2015. Asupan gizidan status gizi vegetarian pada komunitas vegetarian di Yogyakarta. Jurnal Gizi Klinik Indonesia; 11(4): 143-149.

22. Siallagan $D$, Swamilaksita $P D$, Angkasa D. 2016. Pengaruh asupan $\mathrm{Fe}$, vitamin $\mathrm{A}$, vitamin B12, dan vitamin C terhadap kadar hemoglobin pada remaja vegan. Jurnal Gizi Klinik Indonesia; 13(2): 67-74.

23. Matayane SG, Bolang ASL, Kawengian SES. 2014. Hubungan antara asupan protein dan zat besi dengan kadar hemoglobin mahasiswa Program Studi Pendidikan Dokter angkatan 2013 Fakultas Kedokteran Universitas Sam Ratulangi. Jurnal e-Biomedik; 2(3): 1-6. 